\title{
APPLICATION OF THE PUGH METHOD FOR THE SELECTION OF STRUCTURAL ADHESIVES IN PRECISION INSTRUMENTS: A CASE STUDY
}

Marina Reis de Andradea, Valéria Loureiro da Silva ${ }^{a, b}$, Valter Estevão Beala.c

a SENAI Cimatec University Center, Brasil.

b Optics and Photonics, SENAI Cimatec University Center, valeria.dasilva@fieb.org.br

c Industrial Product Development, SENAI Cimatec University Center, valtereb@fieb.org.br

\begin{abstract}
This paper describes a case study of the Pugh method application to the selection of a structural adhesive to be used in the assembly of a precision instrument subsystem. The project team defined the technical requirements and a survey was used to identify the relative weights to be used in the Pugh matrix and select one of the four candidate adhesives. The analysis of the results highlighted the need to also include cost-benefit criteria to achieve the defined goals.
\end{abstract}

Keywords: multi-criteria decision methods; Pugh method; structural adhesives; precision instruments.

\section{APLICAÇÃO DO MÉTODO PUGH PARA A SELEÇÃO DE ADESIVOS ESTRUTURAIS EM INSTRUMENTOS DE PRECISÂO: UM ESTUDO DE CASO}

Resumo: Este artigo descreve a aplicação do método Pugh num estudo de caso voltado para seleção de um adesivo estrutural a ser utilizado na montagem de um dos subsistemas de um instrumento de precisão. A equipe do projeto definiu os requisitos técnicos e uma pesquisa foi utilizada para identificar os pesos relativos que foram aplicados na matriz de Pugh a fim de selecionar uma das quatro alternativas de adesivos. A análise dos resultados evidenciou, também, a necessidade de incluir 0 critério relacionado a custo-benefício para atingir os objetivos definidos.

Palavras-chave: métodos de decisão multicritério; Método de Pugh; adesivos estruturais; instrumentos de precisão. 


\section{INTRODUCTION}

Every product project is made to meet a market need or comes from an innovative idea that can be manufactured and marketed. During the process of product development (PDP), problems often present themselves as multi-criteria problems. These, in turn, require decision making based on factors that subsidize the most appropriate decision aiming at the continuity of product development, without rework. The application of systematic decision-making methods in relation to the selection of concepts/solutions makes the development process more precise, functional, methodical, fast and organized [1, 2].

\subsection{Problem definition}

Although there are different multicriteria decision methods applied to the selection of concepts, there are no evaluations or application examples of these methods for selecting components to be used in the product. This study analyzes the application of a method in the selection of a structural adhesive that has specific characteristics/functions to be met for a given application.

\subsection{Literature review}

The product development process has complexities. These can be even greater when it comes to products with a high level of innovation and needing to develop/enhance technologies to be integrated into the final product. Thus, there are many moments throughout the PDP when the need to choose a solution or component occurs, but there are several criteria to be analyzed. These criteria can, in many cases, be conflicting. In addition, there are qualitative and other quantitative criteria, and in many cases even quantitative criteria are not possible to measure, as they make the project unfeasible, either for the time frame or associated cost. Thus, a systematic way of making choices throughout the project is necessary, considering the manufacturing stage and the total final cost of the product, as well as its functional requirements, which should be analyzed right at the beginning of the design process [2, 3].

Tipically, a PDP process is divided into phases and the first one, sometimes called Informational Phase, is where the requirements are identified and established. This phase is followed by the Conceptual phase where possible concepts and solutions are created and evaluated. The selection amont them should be done in a systematic way, based on the needs or requirements defined in the Informational phase by the client and project team [4].

High precision measuring instruments can be highly sensitive to thermal fluctuations and external vibration noise and should preferably be constructed with modern components and advanced materials to achieve their best performance [5]. However, these advanced components and materials are generally expensive and, depending on the project budget, it is not possible to procure all the ideal items, so the selection involves searching for the best combination of project requirements, material properties and project limitations.

The innovation associated with the development of technologies that result in products with higher quality, productivity and cost reduction fits well with the growing use of structural adhesives to replace some common methods of joining materials (welds, screws, rivets, for example). The application of these adhesives covers several segments, including that of precision instruments. Uniform stress distribution is an important advantage to be considered, as it implies no concentration and absorption of stresses. Vibration damping between the adhesive interfaces may occur, which can 
be desirable or not depending on the application. Another relevant advantage is the possibility of joining materials of different classes. However, theadhesive selection process can be complex since there are many properties that need to be considered for each application and a large variety of products on the market $[12,13,14]$.

The Pugh Method evaluates the ability of each concept to meet the client needs This method consists of comparing the concepts with respect to a range of objectives that reflect the customer needs and consumer value. One of the most common ways to evaluate the generated concepts is by using a matrix, where one concept is selected as a reference and all the others are compared to it. For each evaluation criterion, the matrix can indicate that the concept is "better than", "equal to" or "worse than", as evaluated by the project team. At the end of the analysis, a final score is awarded for each alternative concept and the one with the highest value is indicative of the most appropriate [4, 6, 7].

The concepts selection using the evaluation matrix result in [8]:

- a greater understanding of the requirements;

- a better understanding of the project problem;

- a better understanding of possible solutions;

- an understanding of the interaction between the proposed solutions, which may give rise to other solutions;

- knowledge of the reasons why one concept is stronger or weaker than another;

- an incentive to produce other concepts.

This method can be applied in different areas and approaches as a tool that supports the multi-criteria decision process. Studies aimed at selecting the prototype concept for measuring water loss in humans [9], precision instruments for the agricultural sector [10] and selection of the final concept for an artificial arm model for venous puncture [11] used the Pugh method in order to select the best possible final concept. This approach contributed not only to the final validation of the product under development, but also to the effectiveness of the adopted method, which allows for replicable studies and reduces project costs and production times.

The case study presented here addresses the process of selecting structural adhesives using the Pugh Matrix for building a modular mechanical system which has a part that is regularly removed and replaced. This system has several distinct material interfaces that will be joined using an structural adhesive, whose selection is based on a Pugh Matrix considering the system requirements. Since we are dealing with a process of many variables, the use of multicriteria decision support methods brings a necessary confidence to obtain a path to follow in the next phases of the project.

\section{METHODOLOGY}

A flowchart of the process steps used in this work is presented in Figure 1. The first step is to define the design requirements for a structural adhesive to be used in a modular sub-system of a precision instrument. Those requirements were then translated into nine criteria to be used in the Pugh matrices. Thist step was followed by the development of a Google Forms surveyto assess the importance of each criteria as perceived by the project team members. As the corresponding weights were consistent among the team, the average value was used to define the weights for each criterion, without the need for further discussion. 
After these definitions were done, the Pugh method could be followed, which consists of using a Decision Matrix without weights to identify the best concepts. If these analysis do not lead to a clear decision, a second Matrix with the previously defined weights is applied. The best concept is considered to be the one with the highest score. The result is then validated against the criteria with the highest weigths.

Figure 1: Representative flowchart of the steps of this study.

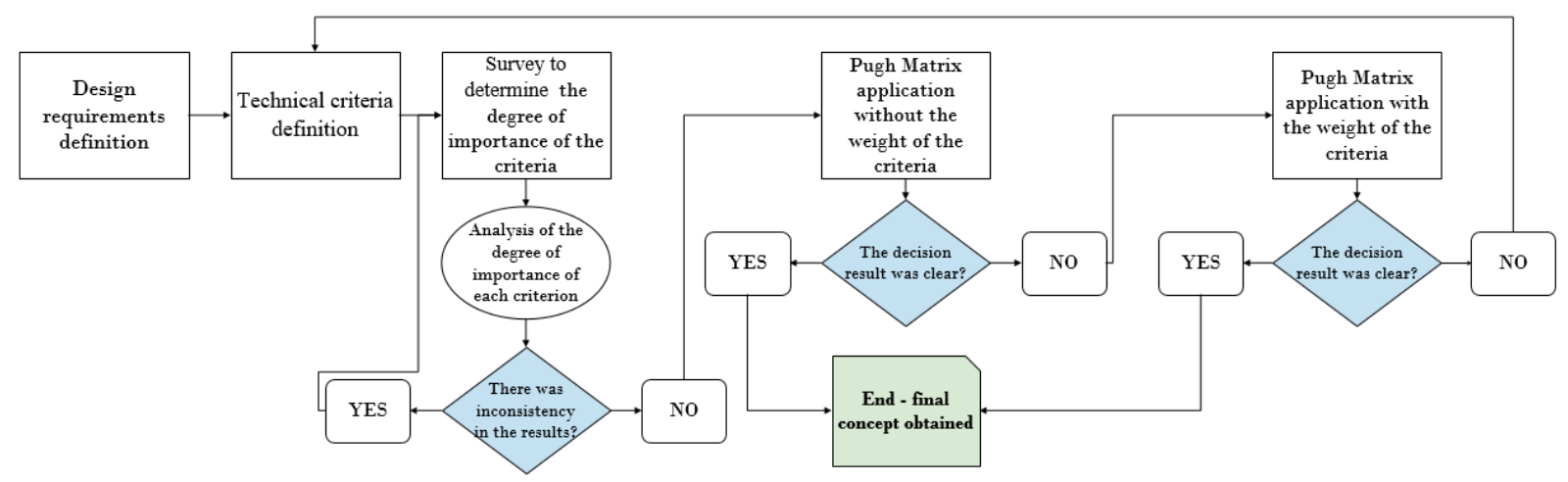

\section{RESULTS AND DISCUSSION}

The interfaces of the subsystem under study that will be joined with the selected adhesive are presented in Table 1. It is observed that the machinable cerâmic is present in 3 different interfaces. The component made with piezoelectric material was purchased ready for final use in the subsystem.

Table 1: Materials of interfaces of the subsystem under study.

Interface 1: machinable ceramic + interface 2: piezoelectric ceramic

Interface 5: machinable ceramic + interface 6: Interface 7: neodymium magnet + interface 8: stainless steel

The following criteria were defined based on the requirements established by the project team for this specific subsystem: higher vibration transfer, strong adherence between interfaces of different materials, low risk of cracking/loss of adhesion after total cure, curing time equal to or less than 24 hours, curing temperature close to room temperature, ease of application, low coefficient of thermal expansion, thickness uniformity after total curing, low shrinkage after total curing.

The reference structural adhesive was EPO-TEK 301, which had been used in earlier prototypes. A search on adhesives available on the Brazilian market with greater viscosity and hardness than the reference and lower total cure time,and thermal expansion coefficient was made. The potential alternatives found for the structural adhesives were: Scotch ${ }^{\circledR}$ Mix $3 M^{\mathrm{TM}}$ Epoxy adhesive, $3 \mathrm{M}^{\mathrm{TM}}$ Scotch-Weld ${ }^{\mathrm{TM}}$ DP-460, SQ-2007 Readelease epoxy adhesive and Lord Corporation 363A/B epoxy adhesive.

The Table 2 presents the Decision Matrix according to the predetermined requirements for the subsystem, considering the adhesive performance in relation to its main properties. The criteria are classified as "worse than" (-), "equal to" (0) and "better than" (+). 
Table 2: Pugh Decision Matrix.

\begin{tabular}{|c|c|c|c|c|c|}
\hline & \multicolumn{5}{|c|}{ Adhesive Alternatives } \\
\hline Criteria & $\begin{array}{c}\text { A1: } \\
\text { Scotch® } \\
\text { Mix 3M }{ }^{\mathrm{TM}} \\
\text { Epoxy } \\
\text { adhesive }\end{array}$ & $\begin{array}{l}\text { A2: } 3 \mathrm{M}^{\mathrm{TM}} \\
\text { Scotch- } \\
\text { Weld }{ }^{\mathrm{TM}} \\
\text { DP-460 }\end{array}$ & $\begin{array}{c}\text { A3: SQ- } \\
2007 \\
\text { Readelease } \\
\text { epoxy } \\
\text { adhesive }\end{array}$ & $\begin{array}{l}\text { A4: Lord } \\
\text { Corporation } \\
\text { 363A/B } \\
\text { epoxy } \\
\text { adhesive }\end{array}$ & $\begin{array}{l}\text { Reference: } \\
\text { EPO-TEK } \\
\quad 301\end{array}$ \\
\hline $\begin{array}{l}\text { High stiffness/transfer } \\
\text { vibration }\end{array}$ & - & + & + & + & 0 \\
\hline $\begin{array}{l}\text { Excellent adhesion } \\
\text { between different } \\
\text { material interfaces. }\end{array}$ & + & + & - & 0 & 0 \\
\hline $\begin{array}{l}\text { Low risk of } \\
\text { cracking/slipping after } \\
\text { full cure. }\end{array}$ & + & + & 0 & + & 0 \\
\hline $\begin{array}{l}\text { Cure time equal to or } \\
\text { less than } 24 \text { hours ( } 1 \\
\text { day). }\end{array}$ & 0 & 0 & - & + & 0 \\
\hline $\begin{array}{llr}\text { Curing temperature } \\
\text { close to room } \\
\text { temperature. }\end{array}$ & 0 & 0 & - & + & 0 \\
\hline $\begin{array}{l}\text { High ease in its } \\
\text { application process. }\end{array}$ & - & - & 0 & 0 & 0 \\
\hline $\begin{array}{l}\text { Low coefficient of } \\
\text { thermal expansion. }\end{array}$ & - & - & - & - & 0 \\
\hline $\begin{array}{l}\text { Uniformity in thickness } \\
\text { after total curing. }\end{array}$ & 0 & 0 & - & 0 & 0 \\
\hline $\begin{array}{l}\text { Low shrinkage after } \\
\text { total cure. }\end{array}$ & 0 & + & - & - & 0 \\
\hline Total + & +2 & +4 & +1 & +4 & 0 \\
\hline Total - & -3 & -2 & -6 & -2 & 0 \\
\hline Total Score & -1 & +2 & -5 & +2 & 0 \\
\hline
\end{tabular}

The alternatives A2 and A4 presented the same total score, but with different strenghs and weaknesses, indicating the need for a new matrix with the weight for each criterion.

Table 3 presents the criteria weights and notes for the adhesive alternatives that will be applied in the weighted decision matrix shown in Table 4 . 
Table 3: Weights and score definitions.

\begin{tabular}{|l|l|}
\multicolumn{1}{|c|}{ Weights } & \multicolumn{1}{c|}{ Value } \\
\hline Weight 1 - indifferent & Value 3 - worse than \\
\hline Weight 3 - not important & Value 5 - equal to \\
\hline Weight 5 - important & Value 7 - better than \\
\hline Weight 7 - strongly important & \\
\hline Weight 9 - extremely important & \\
\hline
\end{tabular}

Table 4: Pugh Weighted Decision Matrix.

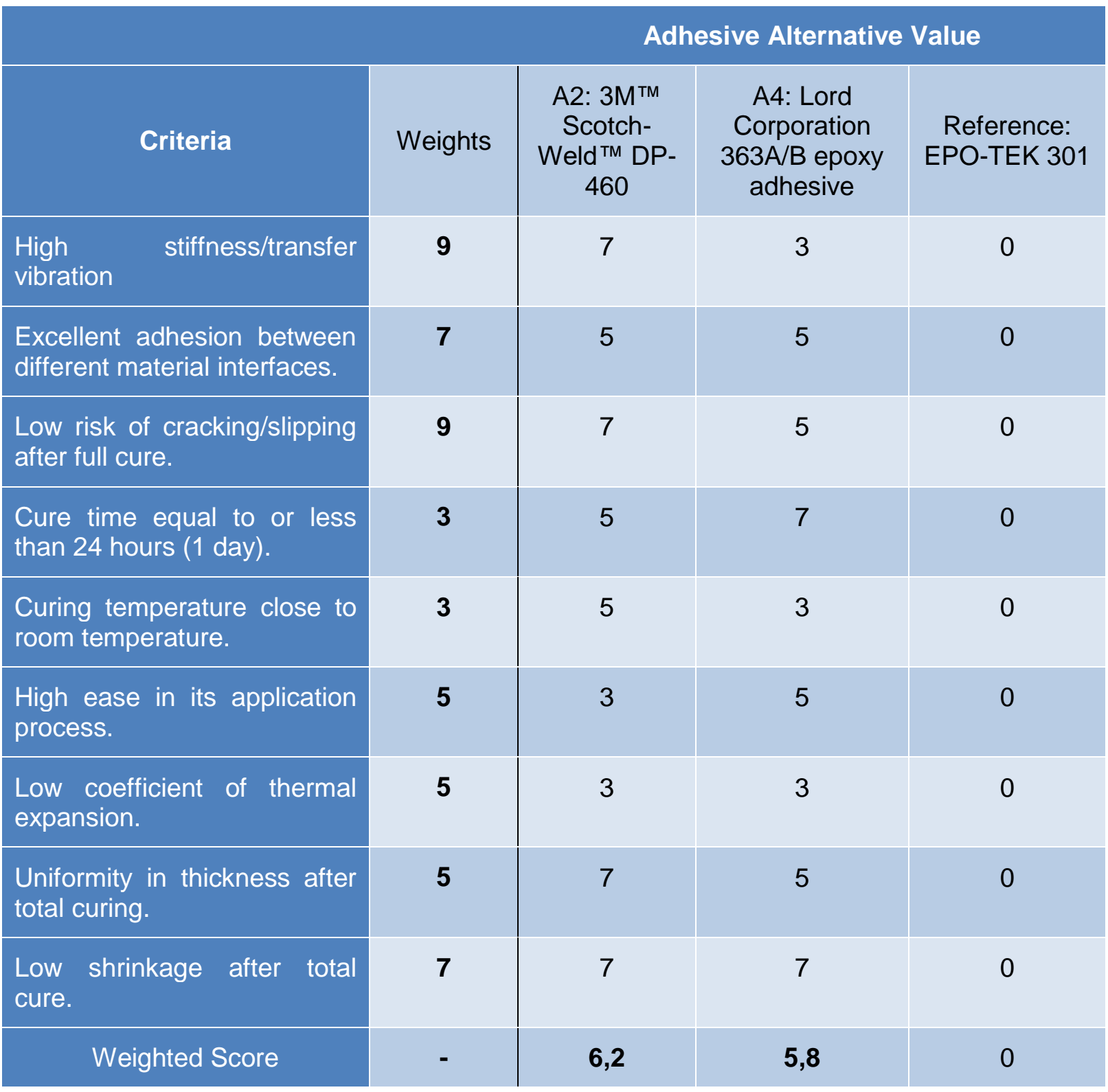


3M Scotch-Weld ${ }^{\mathrm{TM}}$ DP-460 structural adhesive got the highest score and also has the highest values for the extremely and strongly important criteria, namely high stiffness, low risk of detachment after total cure, excellent adhesion between interfaces of different materials and low shrinkage after total cure. The Weighted Decision Matrix used allowed a clearer and more detailed analysis and the selection of an adhesive with superior technical performance. However, the winning adhesive is available only in small quantities (approximately $37 \mathrm{~mL}$ ) and at relatively high relatively high cost. The analysis made for the adhesive selection did not take into account two non-technical important requirements: the adhesive cost and the desire to have a product that can be easily purchased in the national territory, which helps reduce the time of acquisition, testing and product delivery.

\section{CONCLUSION}

This case study demonstrate the use of the Pugh multicriteria decison method to the selection of a component to be used in a product. It was used to select the adhesive for a mechanical subsystem with diverse material interfaces. The DP-460 adhesive met the technical requirements defined as the most important. The preselection of candidate adhesives insured that they were easily obtained in the national territory. However, the associated cost of the selected option was not attractive. In this case, the Pugh method also demonstrated the need for revising the requirements and adjusting the criteria to include the desired cost-benefit aspects of the solution.

\section{Acknowledgments}

The authors are grateful to SENAI Cimatec University Center and the Federal University of Minas Gerais for their support in the technical development of this study, and to EMBRAPII and CODEMGE for the financial aid.

\section{REFERENCES}

${ }^{1}$ DUMOULIN, B.; GUIMARÃES, D.; NEVES, G. O método AHP como ferramenta de focalização do processo de gerenciamento de projetos - Caso: APEX-Brasil. Macroplan- Perspectiva, estratégia e gestão. 2006.

${ }^{2}$ ASHBY, M. E. Seleção de Materiais no Projeto Mecânico. Rio de Janeiro: Elsevier, 2012.

${ }^{3}$ ENSSLIN, L.; ANDREIS, M.; MEDAGLIA, T. A.; CARLI, H. ENSSLIN, S. R. Modelo multicritério para avaliação e seleção de projetos de pesquisa e desenvolvimento em uma empresa distribuidora de energia. Revista Gestão Industrial. Vol. 08, no. 01: pp. 164-198, 2012.

${ }^{4}$ ROZENFELD, H. et al. Gestão de Desenvolvimento de Produtos: uma referência para melhoria do processo. São Paulo: Saraiva, 2006

${ }^{5}$ LEE, Moo-Yeon, SHIM, J., LEE, Dong-Yeon. Precision-structural Design for Scanning Probe Microscopes. Journal of the Korea Academia, vol. 11, no. 11 pp. 4095-4099, 2010. 
${ }^{6}$ CUTOVOI, I. T. M. SALLES, J. A. A. Aplicação do Método Pugh para a Sistematização do PDP na Cadeia de Suprimentos numa Empresa do Segmento Automotivo. IX CNEG - ISSN: 1984-9354, Rio de Janeiro, 2013.

${ }^{7}$ RODRIGUES, L. S. Modelo de aplicação de ferramentas de projeto integradas ao longo das fases de Desenvolvimento de Produto. Dissertação de Mestrado. UFRGS, Porto Alegre, 2008.

${ }^{8}$ LONMO, L; MULLER, G. Concept Selection - Applying Pugh Matrices in the Subsea Processing Domain. Conference Paper in INCOSE International Symposium, 24 (1), 2014.

${ }^{9}$ MOREIRA, D. D. A. Protótipo de um equipamento para registro de perda hídrica em humanos. Monografia. UnB, Brasília, 2018.

${ }^{10}$ WEBER, C. J. Metodologia de desenvolvimento de produtos de precisão com ênfase no uso de sistemas de ajustagem. Dissertação de Mestrado. UFSC, Santa Catarina, 2001.

${ }^{11}$ HÜBNER, G. S. S. Desenvolvimento de um manequim simulador de punção venosa para educação na saúde: da ideia ao protótipo. Dissertação de Mestrado. UFRGS, Porto Alegre, 2015.

12 ADAMS, R. D. Adhesive bonding: Science, technology and applications. $1^{\underline{a}} \mathrm{ed}$. Woodhead Publishing Limited e CRC Press LLC. Inglaterra, 2005.

${ }^{13}$ ADAMS, R. D.; WAKE, W. C. Structural Adhesive Joints in Engineering. Elsevier, 1984.

${ }^{14}$ SILVEIRA, F.; HISTER, W.; KIECKOW, F.; MACHADO, F. M.; COSTA, M. A. B.; AMARAL, F. G.; SANTOS, A. V. Estudo da Aplicação de Adesivos Estruturais para Junção de Chapas de Aço Carbono: Análise da Preparação Superficial do Aderente. ENGEVISTA, vol. 21, № 1, pp. 126-140, 2019. 